\title{
PROFESSORAS INICIANTES NA EDUCAÇÃO INFANTIL E AS NECESSIDADES FORMATIVAS REVELADAS EM TESES E DISSERTAÇÕES PAULISTAS (2009-2019)
}

\author{
Klinger Teodoro Ciríaco ${ }^{1}$, Bruna Cury de Barros ${ }^{2}$, Carolina Marini ${ }^{3}$ \\ ${ }^{1}$ Doutor em Educação pela Universidade Estadual Paulista Júlio de Mesquita Filho - UNESP, campus de Presidente \\ Prudente, São Paulo. Professor Adjunto da Universidade Federal de São Carlos - UFSCar, no Departamento de Teorias \\ e Práticas Pedagógicas - DTPP, do Centro de Educação e Ciências Humanas - CECH. ORCID iD: https://orcid.org/0000- \\ 0003-1694-851X. E-mail: ciriacoklinger@gmail.com \\ ${ }^{2}$ Doutoranda em Educação pela Universidade Federal de São Carlos - UFSCar, na linha de pesquisa: Formação de \\ Professores e outros Agentes Educacionais. ORCID iD: https://orcid.org/0000-0002-9173-4258. E-mail: \\ brunacury.b@gmail.com \\ ${ }^{3}$ Doutoranda em Educação pela Universidade Federal de São Carlos - UFSCar, na linha de pesquisa: Formação de \\ Professores e Outros Agentes Educacionais. ORCID iD: https://orcid.org/0000-0003-1349-8648. E-mail: \\ emailcarolinamarini@gmail.com
}

\section{RESUMO}

Intencionamos caracterizar o que dizem estudos desenvolvidos no período de 2009 a 2019 acerca da temática da "professora iniciante" na Educação Infantil na perspectiva de identificar as necessidades formativas manifestas. Para este fim, mapeamos teses e dissertações defendidas em programas de pósgraduação da área da educação no Estado de São Paulo. O referencial teórico envolve discussões sobre formação de professores, início da docência e as necessidades formativas decorrentes do trabalho pedagógico na Educação Infantil. O percurso metodológico envolveu ampla pesquisa bibliográfica, com enfoque do tipo "Estado da Arte", no sentido de detalhar os focos dos trabalhos, referenciais teóricos, abordagens metodológicas, principais resultados e conclusões. A experiência de localizar a produção do conhecimento dos últimos anos possibilitou-nos compreender que: a) existe poucos estudos que abordam o tema; b) as dificuldades manifestas corroboram dados apresentados pela literatura; c) a identidade docente das professoras sofre influência da visão histórica do caráter assistencialista da Educação Infantil; d) a necessidade de criar iniciativas de formação em contexto, que se adequem as especificidades desta etapa. Frente aos resultados, defendemos a tese de que o processo de iniciação profissional precisa ser encarado como um projeto coletivo, o qual envolve a formação inicial, a formação continuada e a escola como espaços de aprendizagens que deveriam ser mediadas de forma colaborativa.

Palavras-chaves: Professor iniciante. Educação Infantil. Necessidades formativas.

\section{BEGINNING TEACHERS IN CHILDHOOD EDUCATION AND THE FORMATIVE NEEDS REVEALED IN THESIS AND DISSERTATIONS FROM SÃO PAULO (2009-2019)}

\section{ABSTRACT}

We intend to characterize what studies developed from 2009 to 2019 say about the theme of "beginning teacher" in Childhood Education in the perspective of identifying the teacher's training needs. Therefore, we mapped thesis and dissertations from postgraduate programs in the area of Education in the State of São Paulo. The theoretical framework involves discussions about teacher training, the beginning of teaching and the training needs arising from pedagogical work in Childhood Education. The methodological path involved extensive bibliographic research, with a "State of the Art" approach, in order to detail the focus of the thesis and dissertations, theoretical references, methodological approaches, main results and conclusions. The experience of locating the production of knowledge in recent years has enabled us to understand that: a) there are few studies that address the topic; b) the difficulties expressed by teachers corroborate data presented by the literature; c) the identity of teachers is influenced by the historical view of "welfare" of Childhood Education; d) the need to create training initiatives in context that suit the 
specificities of this branch. From the results, we defend the thesis that the professional initiation process needs to be seen as a collective project, which involves initial training, continuing education and the school as the learning space, in which learning should be mediated in a collaborative way.

Keywords: Beginning teacher. Childhood education. Training need.

\section{MAESTRAS PRINCIPIANTES EN EDUCACIÓN INFANTIL Y LAS NECESIDADES DE FORMACIÓN REVELADAS EN TESIS Y DISERTACIONES DE SÃO PAULO (2009-2019)}

\section{RESUMÉN}

Pretendemos caracterizar los estudios desarrollados en el período de 2009 a 2019 sobre "maestra principiante" en Educación Infantil en la perspectiva de identificar las necesidades de formación manifestas. Mapeamos tesis y disertaciones defendidas en programas de posgrado en el área de educación en el Estado de São Paulo - Brasil. El marco teórico involucra discusiones sobre la formación del profesorado, profesores principiantes y las necesidades formativas del trabajo pedagógico en Educación Infantil. El recorrido metodológico implicó una extensa investigación bibliográfica, con un enfoque de "estado del arte", con el fin de detallar el enfoque de los trabajos, referencias teóricas, enfoques metodológicos, principales resultados y conclusiones. Las producciones de conocimiento de los últimos años nos ha permitido comprender que: a) existen pocos estudios que aborden el tema; b) las dificultades manifiestas coinciden con los datos presentados por la literatura; c) la identidad docente de las maestras está influida por la visión histórica de la función asistencial de la Educación Infantil; d) la necesidad de generar iniciativas formativas en contextos que se adapten a las especificidades de esta etapa. Frente a los resultados, defendemos que el proceso de iniciación profesional necesita ser visto como un proyecto colectivo, que implica la formación inicial, la formación continua y la escuela como espacios de aprendizaje que deben ser mediatizados de forma colaborativa.

Palabras clave: Maestra principiante. Educación Infantil. Necesidad de formación.

\section{INTRODUÇÃO}

Desde a década de 1990, pesquisas (LIMA, 1996; FREITAS, 2002) e a própria experiência com a temática, decorrente dos espaços formativos de grupos de pesquisas, debates nos meios acadêmicos e ainda do processo de elaboração das investigações que culminaram em nossos trabalhos de dissertação (BARROS, 2015) e tese (CIRÍACO, 2016), colocamnos em posição de defesa da rica e promissora possibilidade de se caracterizar, de forma mais detalhada, para onde orientam as investigações quando o assunto envolve o "início da docência".

Sem dúvida, estabelecer espaço-tempo para mapear trabalhos investigativos anteriores sinaliza para o contributo que a experiência de levantamento sobre o que dizem as pesquisas pode apresentar à propositura de novas abordagens teóricas e metodológicas para os estudos que envolvem o "professor iniciante". Razão pela qual optamos, neste artigo, por trabalhar com uma abordagem centrada na caracterização de teses e dissertações, no período de 2009 a 2019, na perspectiva de responder o seguinte questionamento:
- Quais necessidades formativas são apontadas em teses e dissertações do Estado de São Paulo em relação ao início da carreira docente na Educação Infantil? Objetivamos caracterizar pesquisas desenvolvidas sobre essa temática visando identificar as necessidades formativas do período relativo à inserção na docência, como também levantar indicadores como alternativas para a minimização dos desafios enfrentados por estes profissionais em ações futuras.

$\mathrm{Na}$ perspectiva de responder a questão geradora do processo do trabalho empreendido no mapeamento, organizamos o texto da seguinte forma: 1) referencial teórico em que apresentamos a discussão do espaço de atuação docente na Educação Infantil e a formação de seus profissionais, inserção na carreira e dificuldades nos primeiros anos da docência em diálogos com o conceito de necessidades formativas; 2) metodologia que descreve o percurso para o levantamento das pesquisas; 3 ) caracterização da produção do conhecimento no período circunscrito para o estudo; 4) considerações finais, momento em que 
apresentamos caminhos possíveis frente às necessidades formativas presentes no desvelar das teses e dissertações localizadas.

\section{EDUCAÇÃO INFANTIL, FORMAÇÃO DE PROFESSORES E O INÍCIO DA DOCÊNCIA}

A Educação Infantil, reconhecida como primeira etapa da Educação Básica, desde a Lei de Diretrizes e Bases da Educação Nacional - №. 9.394, de 20 de dezembro de 1996 (BRASIL, 1996) - encontra, ainda nos anos 2020, uma série de embates teóricos e metodológicos no que respeita a especificidade de atuação de suas profissionais. 0 Art. 62 desta lei destaca que a formação de docentes para atuar nesta etapa farse-á em nível superior, nos cursos de licenciatura plena, e admite, como formação mínima, a oferecida em nível médio, na modalidade normal (BRASIL, 1996).

As práticas pedagógicas desenvolvidas no seio das instituições de educação para a infância, bem como a função da creche e da pré-escola, nunca foram tão discutidas quanto nos tempos atuais. Segundo Lorenzato $(2008$, p. 7), isso ocorre porque "[...] nos últimos anos, em virtude do ingresso cada vez maior da mão-de-obra feminina no mercado de trabalho, o papel dos pais na educação dos filhos tem sofrido mudanças; grandes transformações têm ocorrido na sociedade [...]". Ademais, os avanços tecnológicos que levaram a educação a novos rumos $e$ as novas descobertas sobre 0 desenvolvimento infantil também têm exigido uma concepção de escola diferente a cada dia (LORENZATO, 2008).

Neste contexto, marcada por "duras" lutas históricas, a identidade profissional da professora de infância ${ }^{1}$ tem, nas "armadilhas" das políticas públicas de formação docente, sempre um passo à frente e dois para trás. O princípio básico da organização do trabalho pedagógico com crianças de 0 a 5 anos e 11 meses reconhece ser preciso pensar uma articulação entre práticas de cuidado e educação de forma indissociável, uma vez que os bebês e as crianças pequenas estão em pleno desenvolvimento humano. Entende-se que "[...] se o cuidar também faz parte da educação da criança na escola fundamental (Carvalho, 1999), na educação infantil, que não é obrigatória, esse aspecto

\footnotetext{
1 Tendo em vista a feminização do magistério, em especial na Educação Infantil, e dado ao fato do contexto das pesquisas analisadas terem se desenvolvido com mulheres, fazemos a opção neste texto de nos referirmos ao gênero feminino.
}

ganha uma dimensão mais preponderante quanto menor a idade [...]" (KUHLMANN JR., 2000, p. 13).

O direito à educação e cuidados para as crianças de zero a cinco anos bem como a afirmação do binômio "cuidar e educar" como funções essenciais e indissociáveis nesse atendimento foram, pela primeira vez, reconhecidos pela legislação em nosso país por meio da Constituição de 1988. Posteriormente, a LDB 9.394/96 veio confirmar a função educativa das instituições de Educação Infantil e regulamentar seu funcionamento. Conforme consta no artigo 29 da LDB:

A educação infantil,
primeira etapa da
educação básica, tem
como finalidade 0
desenvolvimento integral
da criança de até 5 (cinco)
anos, em seus aspectos
físico, psicológico,
intelectual e social,
complementando a ação
da família e da
comunidade (BRASIL,
1996).

Para este fim, consideramos ser preciso amplo conjunto de práticas pedagógicas que envolvam os professores, os diretores e os coordenadores das instituições de educação infantil para a construção de um projeto político pedagógico, bem como o conjunto de atividades previstas para esta modalidade de ensino. "Ensinar os conteúdos das áreas na educação infantil requer uma prática interdisciplinar, cabendo ao educador interligar duas ou mais áreas do conhecimento para atingir os objetivos propostos em seu plano de trabalho" (CARVALHO, 2010, p. 15). Pensar em uma proposta de trabalho na infância, nestes moldes, exigirá, sem dúvida, conhecimentos e saberes profissionais que demandam competências e habilidades específicas para atuação com bebês e crianças pequenas. Muitas vezes esses aspectos não são abordados de modo satisfatório em cursos de Pedagogia, razão pela qual é importante pensarmos em como o professor inicia sua atividade docente na Educação Infantil.

Autores como Campos, Grosbaum, Pahim e Rosemberg (CAMPOS et al., 1991), Rocha (1999), Cerisara (2002), destacam desde o início da década de 1990 que é preciso ter uma formação centrada em aspectos de 
desenvolvimento e aprendizagem que atenda a criança como referência da atuação, garantindo seu direito de vivenciar o mundo e viver a infância de modo não escolarizante. Cerisara (2002, p. 334), alerta para essa questão ao afirmar que:

$$
\begin{aligned}
& \text { Para a professora de } \\
& \text { educação infantil existe } \\
& \text { um outro aspecto que } \\
& \text { agrava a situação: a falta } \\
& \text { de ênfase quanto à } \\
& \text { especificidader da } \\
& \text { professora de educação } \\
& \text { infantil nos documentos } \\
& \text { e nas resoluções } \\
& \text { analisados, como se esta } \\
& \text { pudesse ter como base a } \\
& \text { docência nas séries } \\
& \text { iniciais do ensino } \\
& \text { fundamental. Falar em } \\
& \text { professora de educação } \\
& \text { infantil é diferente de } \\
& \text { falar em professora de } \\
& \text { séries iniciais e isso } \\
& \text { precisa ser explicitado } \\
& \text { para que as } \\
& \text { especificidades do } \\
& \text { trabalho das professoras } \\
& \text { com as crianças de } 0 \text { a } 6 \\
& \text { anos em instituições } \\
& \text { coletivas públicas de } \\
& \text { educação e cuidado } \\
& \text { sejam respeitadas e } \\
& \text { garantidas. a do }
\end{aligned}
$$

Partindo da assertiva da autora, podemos inferir que constituir-se professora de crianças pequenas, dadas especificidades, é um desafio contínuo. Por essa razão, olhar para o início da docência destas profissionais é tema emergente e necessário da agenda de pesquisa que defendemos.

De modo comum, muitos são os estudos que problematizam a inserção na carreira e o trabalho de professores iniciantes, contudo, ainda são poucos que dedicam-se a etapa da Educação Infantil (BROSTOLIN; OLIVEIRA, 2013). Segundo Ciríaco e Silva (2020), em um mapeamento de pesquisas em relação ao início da docência, é possível afirmar que há um número reduzido de estudos relativo à Educação Infantil.

Os dados das pesquisas
referenciadas trazem à
tona princípios da
estruturação
investigações de

\begin{abstract}
devemos reconhecer o mérito do esforço teórico-metodológico que demarcam um campo fértil para futuros trabalhos e, ao mesmo, tempo sinalizam para duas grandes lacunas na produção científica: a) a pesquisa sobre professores iniciantes na creche e pré-escola [...] (CIRÍACO; SILVA, 2020, p. 192).
\end{abstract}

Logo, conhecemos bastante, ao menos em termos teóricos, como ocorre a indução profissional em outros espaços da Educação Básica. Isso, sem dúvida, sinaliza para a importância do trabalho que aqui apresentamos.

Nos últimos anos, especialmente na última década, a formação de professores se tornou foco permanente de investigações e propostas governamentais como, por exemplo, o Programa Institucional de Bolsas de Iniciação à Docência - PIBID - e, mais recentemente, a Residência Pedagógica, sendo este último implementado em todo país em 2018 e o primeiro desde meados de 2009 nas Instituições de Ensino Superior (IES's). Em ambos os casos, temos olhares para a formação profissional do futuro professor, ou seja, dos acadêmicos de cursos de licenciatura das mais diversas áreas, o que consideramos um avanço na história das políticas públicas de formação docente.

Ademais, especificamente para o professor que se encontra na fase de início de carreira, no período do tatear da docência (TARDIF, 2007), do choque com o real (VEENMAN, 1984), em vias do "sobreviver" e "descobrir" (HUBERMAN, 2000) os saberes e fazeres de seu ofício, ainda temos poucas iniciativas direcionadas à sua inserção na carreira. Isto é, evidencia-se um número reduzido de trabalhos efetivos com os professores iniciantes na tentativa de contribuir para formas de superação dos desafios que o aprender a ensinar anunciam àquele que está no momento de passagem nos ritos da iniciação (FONTANA, 2000).

A literatura especializada na temática (MARIANO, 2006; MARCELO GARCÍA, 2010) destaca que dentre as principais dificuldades do professor iniciante estão: a) conhecimento da realidade escolar e dos processos que regem as 
ações de organização do ensino; b) gestão de classe; c) relações interpessoais com os colegas de trabalho; d) relação com a família e; e) questões relacionadas tanto à Didática quanto ao conhecimento específico dos conteúdos das áreas do conhecimento que o profissional terá de lecionar.

Sobre dificuldade em relação aos conteúdos, Marcelo García (2010) em uma descrição sobre o professor iniciante, a prática pedagógica e o sentido de sua experiência reitera que as aprendizagens "informais" dos sujeitos na condição de alunos e/ou em contatos diversos com determinada área do conhecimento - pode influenciar sua concepção sobre o que seja ensinar e aprender dentro de um determinado campo. Para o autor:

Se focalizarmos a análise no conteúdo do que se ensina e se aprende, podemos encontrar diferenças no comportamento observável dos professores em função do domínio dos conteúdos. Uma das chaves da identidade profissional se define, sem dúvida, em torno desse tema (MARCELO GARCÍA, 2010, p. 13).

Especificamente no que tange ao trabalho do professor do ensino básico, podemos destacar que a dinâmica da docência nos diferentes níveis de ensino exigirá conhecimentos, competências e habilidades ligadas ao seu desenvolvimento no campo pedagógico, curricular e específico das áreas de sua atuação, como os da Educação Infantil.

No caso do egresso da Pedagogia, por exemplo, a polivalência é destacada desde as Diretrizes Curriculares Nacionais (DCN's) (BRASIL, 2006) como sendo a base formativa. Para tanto, no 2 o artigo deste documento, ao se compreender a docência como "[...] ação educativa e processo pedagógico metódico e intencional, construído em relações sociais, étnico-raciais e produtivas, as quais influenciam conceitos, princípios e objetivos da Pedagogia [...]" (BRASIL, 2006, p. 1), as DCN's reforçam que o perfil do profissional egresso necessita ter um saber polivalente.
O termo polivalência, de acordo com Cruz e Batista Neto (2012, p. 386), "[...] significa assumir múltiplos valores ou oferecer várias possibilidades de emprego e de função, a saber: ser multifuncional; que executa diferentes tarefas; ser versátil, que envolve vários campos de atividade; plurivalente; multivalente". Neste entendimento, seria "[...] polivalente, então, a pessoa com múltiplos saberes capaz de transitar com propriedade em diferentes áreas" (CRUZ; BATISTA NETO, 2012, p. 386).

Logo, pensar a Educação Infantil como espaço de atuação docente exige percebermos diferenças entre seus profissionais em relação aos demais professores, isso porque, de acordo com Rocha (1999, p. 62):

Enquanto a escola se
coloca como espaço
privilegiado para o
domínio dos
conhecimentos básicos, as
instituições de educação
infantil se pom
sobretudo com fins de
complementaridade à
educação da família.
Portanto, enquanto a
escola tem como sujeito o
aluno e como o objeto
fundamental o ensino nas
diferentes áreas através
da aula; a creche e a pré-
escola têm como objeto as
relações educativas
travadas no espaço de
convívio coletivo que tem
como sujeito a criança de
0 a 6 anos de idade (ou até
o momento que entra na
escola).

Entendemos ser preciso desmistificar o caráter da Educação Infantil como sendo um local em que as crianças são admitidas apenas para terem os cuidados com a higiene e alimentação. Muito menos como uma forma de evitar um possível fracasso no Ensino Fundamental, já que não é função desse espaço prepará-la para escolarização futura.

Diante do exposto, percebemos a complexidade em formar professoras da Educação Infantil para atuação na sociedade contemporânea e que de fato estejam preparadas para lidar com as múltiplas nuances que compõem processos de ensinar e aprender na Educação Básica. Sem dúvida decorre, como 
vimos nas reflexões iniciais deste tópico, da inserção no mundo do trabalho algumas necessidades formativas que 0 espaço, as pessoas e a própria organização do cotidiano das instituições de educação da infância apresentam ao professor em início de carreira. Compreendese também que a formação inicial não consegue efetivar os princípios estruturadores de se pensar um currículo que articule "cuidado e educação" como prática indissociável e, menos ainda, promover ampliação de repertório de atuação profissional que permita ao professor de Educação Infantil efetivar vivências com as crianças por meio de "interações e brincadeiras", eixos estruturantes do currículo desta etapa segundo as Diretrizes Curriculares Nacionais para a Educação Infantil (BRASIL, 2010). Na leitura interpretativa que fazemos da problemática em questão, como consequência, a inserção na docência traz consigo novas necessidades formativas.

O estudo de "necessidades formativas" surge nas pesquisas no Brasil na década de 1960. A partir deste período, o direcionamento e operacionalização das ações com os professores vêm se organizando em torno de instrumentos de planejamento e tomadas de decisões educativas, o que se desenvolve na perspectiva de atender exigências sociais e procedimentos considerados eficientes no campo da formação docente (RODRIGUES; ESTEVES, 1993).

Yamashiro e Leite (2012) afirmam que no cenário brasileiro a análise das necessidades formativas dos professores tem sido um amplo indicador para a elaboração de estratégias preliminares ao planejamento e ainda como instrumento diagnóstico de processos formativos. As autoras advogam que o interesse crescente a respeito das necessidades formativas de professores se relaciona com o aumento de ações ligadas a formação permanente (YAMASHIRO; LEITE, 2012).

A determinação das necessidades dos professores como uma das categorias estruturantes dos programas formativos deve levar em conta o fato de, em determinadas vezes, a necessidade não revelar-se em razão do desconhecimento que os próprios professores possuem a respeito da natureza de novas exigências do trabalho profissional. Por isso, fazse necessário a reflexão da prática orientada por perspectivas teóricas que possibilitem questionar a própria prática e dar origem a novas necessidades para o aperfeiçoamento do trabalho profissional (NÚÑEZ, 2004, p. 5).

Ademais, a discussão até aqui referenciada nos coloca no posicionamento de pensar ações que visem o acompanhamento de professores iniciantes a partir do diagnóstico de suas necessidades de formação. Desta forma, é possível pensar tanto em políticas públicas de apoio à indução na docência quanto em iniciativas de formação inicial e continuada, as quais possibilitem auxiliar a "sobreviver" nessa fase e a "descobrir" os encantos da profissão no espaço-tempo da Educação Infantil junto às crianças.

Em síntese, diante da discussão posta ao longo do referencial teórico destacado, para que o atendimento de necessidades formativas das profissionais de Educação Infantil se efetive, no sentido de auxiliar/contribuir para o aprimoramento da docência, entendemos ser preciso encarar o início da atividade profissional como um projeto coletivo.

\section{METODOLOGIA}

A abordagem metodológica que respalda a natureza das ações empreendidas no mapeamento realizado é de cunho qualitativo, de caráter descritivo-analítico, desenvolvida sob a perspectiva "Estado da Arte". Este tipo de estudo permite ao pesquisador contato direto com a situação e/ou pessoas investigadas, prima pela descrição de fatos/eventos, sentimentos e interpretações das pessoas sobre determinados assuntos/objetos, dá ainda a possibilidade de olharmos para além do observável, transcendendo o não-ditos, para que se possa tecer considerações sob a luz de um referencial teórico.

Para Denzin e Lincoln (1994, p. 2), a investigação qualitativa:

[...] é multimetodológica quanto ao seu foco, envolvendo abordagens interpretativas 
naturalísticas de assuntos. Isto significa que o pesquisador qualitativo estuda coisas em seu ambiente natural, tentando dar sentido ou interpretar os fenômenos, segundo o significado que as pessoas lhe atribuem.

Neste contexto, sobre o método do tipo "Estado da Arte", entendemos que este se inclui no campo dos "multimétodos" da pesquisa qualitativa citados por Denzin e Lincoln (1994). Isso porque temos a impressão de que não conhecemos, por mais que esforçamos para tal, em totalidade os estudos e pesquisas de determinadas áreas, a exemplo a produção sobre "professores iniciantes" e "início da docência na Educação Infantil". Ferreira (2002, p. 258-259) indica que algumas áreas apresentam "[...] crescimento tanto quantitativo quanto qualitativo, principalmente reflexões desenvolvidas em nível de pós-graduação, produção esta distribuída por inúmeros programas de pós e pouco divulgada".

Logo, levanta-se a necessidade de trabalhos com foco em mapear, em espaçotempo, o que dizem teses e dissertações. Este tipo de perspectiva metodológica, segundo Ferreira (2002), se sustenta e motiva em conhecer o que já fora produzido para se buscar, posteriormente, o que não se fez. Além disso, pesquisadores que se valem de mapeamento em relação à algum assunto, "[...] trazem em comum a opção metodológica, por se constituírem pesquisas de levantamento e de avaliação do conhecimento sobre determinado tema" (FERREIRA, 2002, p. 259). Desse modo, pretendem dar conta de sistematizar determinado saber e divulgá-lo à sociedade, isso é o que estruturamos neste paper.
Por estarmos a falar de um tipo de abordagem de pesquisa peculiar, intencionamos tomar contato com os trabalhos e "[...] através da quantificação e de identificação de dados bibliográficos, com o objetivo de mapear essa produção num período delimitado, em anos, locais, áreas de produção" (FERREIRA, 2002, p. 265). Contudo, não no sentido de esgotar as discussões e muito menos de dar visibilidade a tudo que fora produzido, mas sim, destacar teses e dissertações sobre professores iniciantes na Educação Infantil, no período de 2009 a 2019, defendidas em Programas de Pós-Graduação em Educação de Universidades localizadas no Estado de São Paulo.

Para realização do mapeamento, primeiramente foi necessário acessar o site da Plataforma Sucupira para identificar quais IES's públicas e privadas do Estado de São Paulo possuíam Mestrado e Doutorado (em funcionamento). Verificou-se no total 19 instituições que se adequavam aos requisitos delimitados nesta pesquisa. O próximo passo foi realizar um levantamento das dissertações e teses disponíveis nos repositórios virtuais dessas Universidades que tratavam sobre o início da docência. Para tal, utilizou-se como filtro de busca os seguintes termos no título e assunto dos trabalhos: "professor iniciante"; "professores iniciantes"; "início da docência"; "inserção na docência". Ressalta-se que alguns repositórios não tinham um espaço de busca/filtro de termos, nestes casos foi necessário ler o título de todos os trabalhos publicados entre os anos de $2009 \mathrm{e}$ 2019.

Neste primeiro levantamento, foram selecionadas 52 pesquisas que trataram sobre o início na carreira docente em diferentes etapas de ensino, como: Educação Infantil, Ensino Fundamental, Ensino médio, Educação de Jovens e Adultos e Ensino Superior. A seguir, a tabela 1 especifica a quantidade de trabalhos científicos publicados em cada ano:

Tabela 1. Teses e dissertações sobre "Professores Iniciantes" (2009-2019) em programas de pósgraduação paulistas.

$\begin{array}{llllllllllll}2009 & 2010 & 2011 & 2012 & 2013 & 2014 & 2015 & 2016 & 2017 & 2018 & 2019 & \text { TOTAL }\end{array}$

$\begin{array}{llllllllllll}3 & 3 & 3 & 1 & 3 & 7 & 6 & 9 & 6 & 7 & 4 & 52\end{array}$

Fonte: Os autores. 
Verificou-se ainda que a grande maioria das dissertações e teses sobre professores iniciantes estavam vinculadas a Programas de Pós-Graduação de Universidades públicas. É também bastante relevante a produção de pesquisas sobre o tema na Universidade Federal de São Carlos (UFSCar), totalizando 23 trabalhos publicados - quase a metade de toda a produção encontrada no levantamento - assim como demonstra a tabela 2 .

Tabela 2. Pesquisas sobre "Professores Iniciantes" por Instituição (2009-2019)

\begin{tabular}{|c|c|c|c|c|c|c|c|c|c|c|c|}
\hline & 2009 & 2010 & 2011 & 2012 & 2013 & 2014 & 2015 & 2016 & 2017 & 2018 & 2019 \\
\hline $\begin{array}{c}\text { PUC- } \\
\text { Campinas }\end{array}$ & - & - & - & - & - & - & - & - & - & - & - \\
\hline $\begin{array}{c}\text { UNESP- } \\
\text { Araraquara }\end{array}$ & - & - & - & - & - & - & 1 & 2 & 2 & - & - \\
\hline $\begin{array}{c}\text { UNESP - } \\
\text { Presidente } \\
\text { Prudente }\end{array}$ & - & - & 1 & - & - & - & - & 2 & - & - & - \\
\hline $\begin{array}{l}\text { UNESP - } \\
\text { Marília }\end{array}$ & - & - & - & - & - & - & - & - & - & - & - \\
\hline $\begin{array}{c}\text { UNESP - Rio } \\
\text { Claro }\end{array}$ & - & 1 & - & - & 1 & 1 & - & - & 1 & 1 & - \\
\hline $\begin{array}{c}\text { Universidad } \\
\text { e Metodista } \\
\text { de } \\
\text { Piracicaba - } \\
\text { UNIMEP }\end{array}$ & - & - & - & - & - & - & - & - & 1 & - & - \\
\hline $\begin{array}{c}\text { UFSCar-São } \\
\text { Carlos }\end{array}$ & 1 & 2 & - & - & 2 & 6 & 4 & 2 & - & 3 & 3 \\
\hline $\begin{array}{l}\text { UFSCar- } \\
\text { Sorocaba }\end{array}$ & - & - & - & - & - & - & - & 2 & 1 & - & - \\
\hline $\begin{array}{c}\text { UFSCar- } \\
\text { Educação } \\
\text { Especial }\end{array}$ & - & - & - & - & - & - & - & - & - & - & - \\
\hline UNINOVE & - & - & 1 & - & - & - & - & - & - & - & - \\
\hline UNISANTOS & 2 & - & - & - & - & - & - & - & - & - & - \\
\hline UNISO & - & - & - & - & - & - & - & - & - & - & - \\
\hline UNOESTE & - & - & - & - & - & - & - & 1 & - & - & - \\
\hline USF & - & - & - & 1 & - & - & - & - & - & - & - \\
\hline $\begin{array}{c}\text { USP - } \\
\text { Ribeirão } \\
\text { Preto }\end{array}$ & - & - & - & - & - & - & - & - & 1 & 1 & - \\
\hline $\begin{array}{c}\text { USP - São } \\
\text { Paulo }\end{array}$ & - & - & 1 & - & - & - & - & - & - & - & - \\
\hline UNIFESP & - & - & - & - & - & - & - & - & - & 1 & - \\
\hline UNICAMP & - & - & - & - & - & - & 1 & - & - & 1 & 1 \\
\hline UNICID & - & - & - & - & - & - & - & - & - & - & - \\
\hline
\end{tabular}

Fonte: Os autores.

A fim de selecionar apenas dissertações e teses que tratavam sobre professores iniciantes da Educação Infantil, foco desta pesquisa, foi realizada a leitura dos resumos de cada um dos trabalhos científicos. Em alguns casos os resumos não ofereceram as informações sobre os objetivos e sujeitos da pesquisa, por isso tornou- se necessária a leitura de outras partes dos textos, como: introdução e percurso metodológico. Após essa leitura atenta, selecionaram-se apenas quatro pesquisas: três dissertações e uma tese.

Identificados os trabalhos que serviram de mote para a discussão que propusemos, estes 
foram apreciados criticamente com a finalidade de identificar seus focos de investigação, objetivos, referenciais teóricos, materiais e métodos, principais resultados e conclusões. Cumpre salientar que o esforço empreendido por nós, na leitura minuciosa da tese e dissertações mapeadas, direcionou-se com base na busca por respostas à questão que apresentamos na introdução do artigo.

\section{DISCUSSÃO DOS RESULTADOS}

As pesquisas mapeadas na última década que correlacionam o início da docência com a Educação Infantil foram, como vimos na seção metodológica, quatro trabalhos (uma tese e três dissertações). A identificação mais detalhada é exposta no quadro a seguir em ordem crescente do ano de publicação:

Quadro 1. Pesquisas sobre "Professores Iniciantes" que atuam na Educação Infantil

\begin{tabular}{|c|c|c|c|c|c|}
\hline NOME DA PESQUISA & AUTORA & ORIENTADOR(A) & TIPO & INSTITUIÇÃO & ANO \\
\hline $\begin{array}{l}\text { APRENDIZAGEM PROFISSIONAL } \\
\text { DA DOCÊNCIA: QUE SABERES O(A) } \\
\text { PROFESSOR(A) TEM PARA ATUAR } \\
\text { EM CRECHE? }\end{array}$ & $\begin{array}{c}\text { Monique } \\
\text { Aparecida } \\
\text { VOLTARELLI }\end{array}$ & $\begin{array}{l}\text { Profa. Dra. } \\
\text { Maria lolanda } \\
\text { MONTEIRO }\end{array}$ & Dissertação & $\begin{array}{l}\text { UFSCar - } \\
\text { São Carlos }\end{array}$ & 2013 \\
\hline $\begin{array}{l}\text { SER PROFESSORA INICIANTE NA } \\
\text { EDUCAÇÃO INFANTIL: } \\
\text { APRENDIZAGENS E } \\
\text { DESENVOLVIMENTO } \\
\text { PROFISSIONAL EM CONTEXTO DE } \\
\text { ENFRENTAMENTOS E SUPERAÇÕES } \\
\text { DE DILEMAS }\end{array}$ & $\begin{array}{c}\text { Bruna Cury de } \\
\text { BARROS }\end{array}$ & $\begin{array}{c}\text { Profa. Dra. } \\
\text { Maristela } \\
\text { ANGOTTI }\end{array}$ & Dissertação & $\begin{array}{l}\text { UNESP - } \\
\text { Araraquar } \\
\text { a }\end{array}$ & 2015 \\
\hline $\begin{array}{l}\text { A INSERÇÃO PROFISSIONAL E A } \\
\text { ATUAÇÃO DOCENTE NA } \\
\text { EDUCAÇÃO INFANTIL }\end{array}$ & $\begin{array}{l}\text { Midiã Olinto de } \\
\text { OLIVEIRA }\end{array}$ & $\begin{array}{l}\text { Profa. Dra. Alda } \\
\text { Junqueira } \\
\text { MARIN }\end{array}$ & Tese & $\begin{array}{c}\text { PUC - } \\
\text { São Paulo }\end{array}$ & 2018 \\
\hline $\begin{array}{l}\text { APRENDIZAGEM DA DOCÊNCIA: o } \\
\text { QUE REVELAM AS TRAJETÓRIAS } \\
\text { DAS PROFESSORAS DE EDUCAÇÃO } \\
\text { INFANTIL DA REDE MUNICIPAL DE } \\
\text { RIBEIRÃO PRETO }\end{array}$ & $\begin{array}{c}\text { Tawana } \\
\text { Domeneghi } \\
\text { Orlandi TOSTA }\end{array}$ & $\begin{array}{l}\text { Profa. Dra. Ana } \\
\text { Paula Gestoso } \\
\text { de SOUZA }\end{array}$ & Dissertação & $\begin{array}{l}\text { UFSCar - } \\
\text { São Carlos }\end{array}$ & 2019 \\
\hline
\end{tabular}

Fonte: Os autores.

Os trabalhos científicos foram lidos minuciosamente a fim de que fosse possível levantar dados referentes às dificuldades do início da docência por professoras da Educação Infantil, além de outras informações que oferecessem indícios das necessidades formativas dessas profissionais. A seguir, apresenta-se brevemente os conteúdos tratados nas dissertações e na tese, bem como discussão dos resultados encontrados.

"APRENDIZAGEM PROFISSIONAL DA DOCÊNCIA: QUE SABERES O(A) PROFESSOR(A) TEM PARA ATUAR NA CRECHE?" (VOLTARELLI, 2013)

O primeiro trabalho localizado no período circunscrito foi o de Voltarelli (2013). $\mathrm{Na}$ busca de compreender: "Como se configuram os saberes docentes de professoras iniciantes para atuar em creches?" (VOLTARELLI, 2013, p. 10, destaques da autora), a pesquisadora empreendeu esforços para discutir aspectos da aprendizagem da docência e desenvolvimento profissional. $O$ trabalho se refere a uma pesquisa de natureza qualitativa, em Centros Municipais de Educação Infantil de uma cidade do interior do Estado de São Paulo, especificamente com três professoras iniciantes que atuavam com turmas de zero a três anos. O objetivo geral fora investigar quais saberes a professora necessita ter para trabalhar na creche, bem como em que medida estes saberes se configuram na prática das três docentes que atuam no sistema público pesquisado e como aprendem os ofícios de sua profissão (VOLTARELLI, 2013).

A fundamentação teórica mobilizou aspectos sobre aprendizagem da docência, início de carreira e políticas de formação de professores com destaques para a Educação Infantil em um resgate do processo de constituição da identidade das instituições no 
Brasil. Nesta direção, defende-se a tese de que dada a importância de discussão "de" e "sobre" como se aprende a ser professor alguns pontos são fundamentais, a saber:

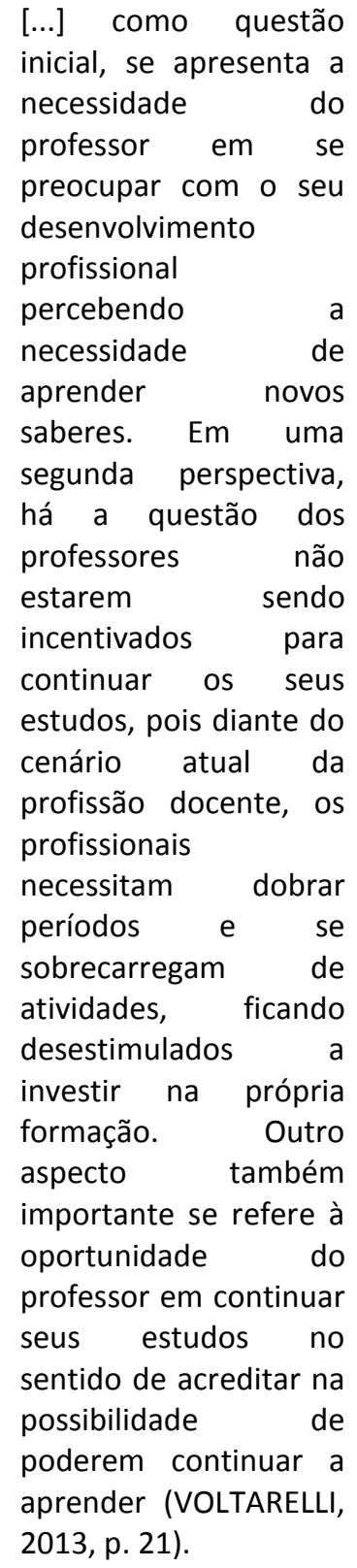

A metodologia adotada para a abordagem e tratamento das questões inerentes à dissertação foi a pesquisa qualitativa. $O$ critério de seleção das professoras iniciantes foi: ser formada em Pedagogia; ter o enquadramento funcional efetivo; e ter até cinco anos de experiência profissional. "Esta escolha se deve também ao fato de um professor iniciante se deparar com situações diversas no início da carreira, vivenciando o trabalho com profissionais que também estão ingressando agora e com aqueles que já estão na prefeitura há muito tempo" (VOLTARELLI, 2013, p. 105).
Os instrumentos de produção dos dados e informações coligidas e organizadas no texto foram: roteiros de entrevistas semiestruturadas, observação das práticas pedagógicas constituídas na creche; diário de campo da pesquisadora; e análise documental. Existe uma particularidade sobre o ingresso na docência na rede pesquisada, segundo a autora:

[...] ao ingressarem na Rede Municipal de Educação onde a pesquisa foi realizada, ficam por um período de dois anos lotados na Secretaria Municipal de Educação e Cultura desenvolvendo atividades docentes, tais como substituição de licença maternidade, afastamentos; substituindo os docentes que estão em cargos de confiança e atuando em projetos desenvolvidos pela Secretaria (LEI № 13.889/86), devido a esse fato as professoras ficam circulando pelos CEMEls, sofrendo diversas influências e conhecendo outras realidades educacionais (VOLTARELLI, 2013, p. 108-109.).

A descrição e análise de dados teve como fonte informações angariadas na observação de, aproximadamente, um mês em cada turma, o que totalizou quase 15 sessões nas aulas das professoras. Diante da experiência de contato direto com o ambiente, Voltarelli (2013, p. 110), por também ser professora de Educação Infantil, menciona que seu grande desafio "[...] foi de inserção em um contexto de pesquisa que é o mesmo ambiente de trabalho, pois como observadora participante, ao mesmo tempo modifica e é modificado pelo contexto sob observação".

Os eixos analíticos, possibilitamos pelo cruzamento das múltiplas fontes de produção de dados, permitiram eleger as seguintes 
categorias: 1) "concepção de criança e de creche"; 2) "proposta pedagógica da Instituição de Educação Infantil"; 3) "cuidado e educação"; 4) "conteúdos ensinados para crianças de zero a três anos"; e 5) "aprendizagem da docência na creche".

Os resultados evidenciam que as professoras colaboradoras do trabalho, as quais foram objeto de reflexão por meio de práticas observadas e entrevistas, não conseguiram nomear os saberes e fontes de aprendizagens. Contudo, têm ciência do que fazer e onde buscar materiais de apoio para fundamentação de suas atividades permanentes com as crianças. Além disso, demonstram, por vezes, desânimo e sentemse desmotivadas em relação ao desenvolvimento profissional no início da docência, transitando entre "[...] dificuldades do trabalho na creche e práticas bemsucedidas com as crianças" (VOLTARELLI, 2013, p. 210). Sobre a organização do trabalho pedagógico com faixa etária de 0 a 3 anos, relataram que este exige especificidades que diferem-se pela característica do desenvolvimento infantil. Mencionaram que não participaram da elaboração do projeto político pedagógico das instituições em que atuam, "[...] nem todas têm conhecimento sobre o que o PPP da instituição pretende realizar" (VOLTARELLI, 2013, p. 210).

Neste estudo, de modo explícito, a pesquisadora afirma que as professoras iniciantes assumem muitas responsabilidades sozinhas e sem apoio da gestão das instituições. Destacaram que seria importante a perspectiva de trabalho colaborativo e um planejamento efetivo que prime pela participação ativa de todas as docentes e ainda o compartilhamento das práticas para que se amplie o repertório didático-pedagógico com as crianças, o que não ocorreu. Este tipo de ação é, para Voltarelli (2013), fonte de aprendizagem da docência que influencia, de forma significativa, no trabalho das professoras iniciantes.

Outro dado recorrente observado no cotidiano das instituições de Educação Infantil, foi que parece existir uma hierarquização em relação à creche e pré-escola. Tal diferenciação ocorreu porque a dinâmica de atendimento das crianças na creche exige perspectivas de cuidado e educação específicos, o que não ocorre com crianças de
3 a 5 anos e 11 meses. Nas instituições pesquisadas, as professoras iniciantes conviviam, cotidianamente, com professoras da pré-escola, isso trouxe uma visão das profissionais da creche como "crecheiras, pajens, babás e tias" e as outras se colocavam como superiores, portanto, com status de "professora". Apesar de terem, no trato diário, a mesma terminologia de "tia", a instituição de Educação Infantil parece, no caso pesquisado, ter uma visão de que o trabalho educacional é realizado, de modo mais efetivo por "professoras" com crianças maiores.

Em síntese, face aos dados, a conclusão central da dissertação é que faz-se preciso perspectivas e ações formativas centradas no ambiente de trabalho do professor, as quais incorporam projetos coletivos.

\section{"SER PROFESSORA INICIANTE NA EDUCAÇÃO INFANTIL: APRENDIZAGENS E DESENVOLVIMENTO PROFISSIONAL EM CONTEXTO DE ENFRENTAMENTOS E SUPERAÇÕES DE DILEMAS" (BARROS, 2015)}

A dissertação de mestrado de Barros (2015) se refere a uma pesquisa de abordagem qualitativa que buscou compreender a constituição da profissionalidade de professoras iniciantes que atuavam na educação infantil. Para o desenvolvimento da pesquisa, a autora se embasou em teóricos que discutem sobre formação de professores, ciclo de vida profissional, inserção na docência e Educação Infantil.

Para a seleção dos sujeitos participantes, Barros (2015) enviou um formulário Google com perguntas fechadas para os egressos do curso de Pedagogia de uma Universidade pública do estado de São Paulo. A intenção era levantar informações da trajetória profissional desses sujeitos. Após o recebimento das respostas, a pesquisadora entrou em contato com todos os egressos que tinham até cinco anos de experiência e que atuavam em instituições públicas e/ou privadas de Educação Infantil. Cinco professoras que atuavam nesta etapa aceitaram participar da pesquisa.

A coleta de dados aconteceu por meio de entrevistas individuais que seguiram um roteiro semiestruturado. Durante a realização dessa técnica, Barros (2015) questionou as participantes sobre o processo de formação inicial, o início da docência na Educação Infantil, o 
contexto de trabalho, as dificuldades e conquistas relacionadas à atuação profissional, as concepções das professoras iniciantes sobre a Educação Infantil e a docência nesta etapa.

De acordo com Barros (2015, p. 145), as narrativas das professoras iniciantes participantes indicaram que:

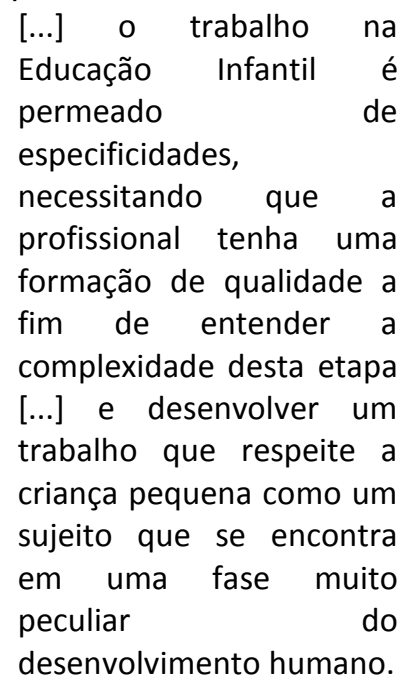

Neste processo de descoberta sobre o fazer docente na Educação Infantil, as entrevistadas relataram situações de conflito e dificuldades muito semelhantes, como: falta de apoio; pouca relação com os pares e as famílias; precárias condições de trabalho; insegurança sobre "o que" e "como" fazer; choque de realidade. Barros (2015) salienta que os desafios dessas professoras se relacionavam a questões de âmbito pessoal, formativo e institucional.

Apesar das dificuldades provenientes do trabalho provocar sentimentos de solidão, insegurança e frustração, estas situações também se mostraram como um momento de aprendizagem e desenvolvimento profissional para as iniciantes. Isto é, a partir dos desafios vivenciados, as professoras pareciam refletir sobre o ocorrido e buscar alternativas para enfrentá-los e, até mesmo, superá-los (BARROS, 2015).

Os resultados da dissertação indicam a importância do suporte de professores mais experientes, coordenadores e diretores das instituições para que o professor iniciante consiga lidar com as dificuldades do trabalho e aprimore a sua prática pedagógica. De acordo com Barros (2015, p. 143), "[...] quando as professoras recebiam esse apoio se sentiam fortalecidas, mais motivadas a trabalharem, 0 que propiciava a construção de uma identificação com o fazer na Educação Infantil".
Além do apoio institucional, a formação inicial e continuada também foram elementos importantes que favoreceram a descoberta da profissão e a construção da identidade profissional. Entretanto, Barros (2015) salienta a importância e necessidade de se ter maior aproximação Universidade-Escola, pois a articulação dos saberes provenientes dessas instituições pode favorecer o processo formativo de futuros professores e professores iniciantes.

Por fim, a autora apresenta como contribuição de sua pesquisa a evidência de que:

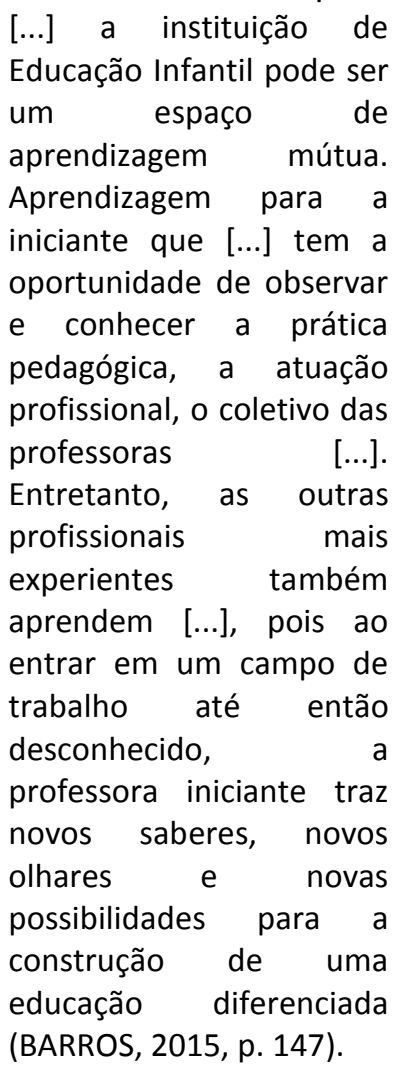

Neste sentido, partindo dos resultados da pesquisa, Barros (2015) considera que a instituição de Educação Infantil pode se tornar um ambiente importante para a formação dos professores, principalmente quando há trocas de saberes, experiências, conhecimentos entre os profissionais a fim de aprimorar o trabalho pedagógico.

\section{"A INSERÇÃO PROFISSIONAL E A ATUAÇÃO DOCENTE NA EDUCAÇÃO INFANTIL" (OLIVEIRA, 2018)}

A tese de doutorado desenvolvida por Oliveira (2018) teve como objetivo investigar a atuação de professoras da Educação Infantil durante o período de inserção na docência. Tendo como propósito analisar o processo de formação e atuação profissional dos sujeitos da 
pesquisa, a autora embasou o seu estudo na perspectiva histórico-cultural e nos conceitos de "habitus" e "capital cultural" de Bourdieu.

Participaram da pesquisa quatro professoras que atuavam em uma sala de Berçário II - turma que atendia crianças de dois a três anos de idade - de uma creche municipal na cidade de Guarulhos. Duas dessas professoras estavam iniciando a carreira docente. Os dados foram coletados por meio das seguintes técnicas: i) primeiramente foi aplicado um questionário com perguntas abertas e fechadas a fim de coletar informações do perfil das participantes; ii) realizou-se entrevistas individuais semiestruturadas; iii) por fim, observação sistemática da prática das professoras no contexto de trabalho. Oliveira (2018, p. 158-159), apresenta como realizou a observação participante:

\begin{abstract}
Nas primeiras quatro semanas [...] ocorreram em quatro dias da semana [...]. No segundo mês, as observações foram reduzidas para três dias na semana e, a partir de abril, a frequência foi estabilizada em duas vezes por semana. [...]. Se, no primeiro semestre, havia apenas uma professora iniciante (Renata), no segundo, com a professora Graziele substituindo a Fabiana que assumiu a coordenação pedagógica em outra escola, tivemos duas professoras iniciantes, mas, em situações diferentes [...]: a professora Renata efetivamente ingressou no magistério, sem ter experiências anteriores [...]. Já a professora Graziela era iniciante apenas no exercício da docência na Educação Infantil.
\end{abstract}

A professora iniciante Renata é formada em Pedagogia e escolheu atuar na Educação Infantil devido às experiências dos estágios durante a formação inicial. Até a data da realização da pesquisa, Renata possuía apenas três anos de carreira - tendo atuado somente na creche - e, de acordo com o questionário respondido, considerava necessário para o desenvolvimento do trabalho nesta etapa os seguintes aspectos: "[...] conhecimentos de técnicas e recursos pedagógicos, interesse por questões educacionais e conhecimentos de psicologia infantil" (OLIVEIRA, 2018, p. 169). A participante ressalta que a grande contribuição da formação inicial foi reconhecer que "[...] não importa o tempo de profissão docente, é necessário estar em constante busca para aperfeiçoar a prática" (OLIVEIRA, 2018, p. 170 grifo da autora).

A professora Graziela cursou o magistério e, posteriormente, se formou em Pedagogia. Ela tinha 15 anos de experiência docente - atuando no Ensino Fundamental, principalmente com a alfabetização inicial, e na Educação de Jovens e Adultos -, porém era iniciante na Educação Infantil tendo apenas dois anos de carreira. De acordo com o questionário, Graziela considerava - em ordem de prioridade - que para atuar na creche a professora deveria ter "[...] controle sobre o comportamento das crianças, conhecimentos de técnicas e recursos pedagógicos e interesse por questões educacionais" (OLIVEIRA, 2018, p.172). A professora também indica que a especificidade do trabalho pedagógico na Educação Infantil se relaciona à peculiaridade da rotina com as crianças pequenas. Segundo Graziela, a maior contribuição da sua formação inicial foi evidenciar "[...] o caráter contínuo de formação e aperfeiçoamento do professorado [...]. Também destacou as experiências de estágio como aspecto fundamental em seu processo de formação" (OLIVEIRA, 2018, p. 172).

Os dados coletados nas situações de questionário, entrevista e observação participante ofereceram indícios de que:

[...] na proposição de atividades e experiências formativas às crianças, prevalece uma conceptualização naturalizada do desenvolvimento infantil e uma concepção da criança como protagonista na construção de seus próprios conhecimentos [...] Predominam, assim, na rotina de trabalho da creche, brincadeiras livres e espontâneas, sem 


$$
\begin{aligned}
& \text { intervenções } \\
& \text { mediações docentes e um } \\
& \text { trabalho pedagógico } \\
& \text { marcado pela não } \\
& \text { diretividade (OLIVEIRA, } \\
& \text { 2018, p. 261). }
\end{aligned}
$$

Referente às dificuldades que enfrentaram durante o trabalho pedagógico na creche, as professoras iniciantes relataram: elaboração do planejamento pedagógico; controle e manejo da sala; comunicação com as crianças; não saber lidar com o período de adaptação; pouco domínio de conteúdos adequados à faixa etária das crianças; baixa familiaridade com a rotina. As condições precárias da escola, tanto no que diz respeito aos espaços físicos (manutenção e tamanho das salas) como a falta de recursos materiais, demonstrou ser um dificultador no desenvolvimento de uma prática pedagógica de qualidade e adequada à Educação Infantil. Além de aspectos relacionados ao trabalho pedagógico em si, verificou-se que as professoras enfrentaram dúvidas em questões mais administrativas como, por exemplo, no preenchimento de formulários, diários e documentos.

Também podem ser observadas algumas relações conflituosas com as famílias das crianças, principalmente em situaçõesproblemas, e com algumas professoras da escola. Neste caso, a professora iniciante Renata explicita que sentia a desvalorização da profissão tanto por parte dos pais como também dos pares que atuavam no ensino fundamental (OLIVEIRA, 2018).

Tanto a narrativa da professora Renata como a de Graziela explicitam que contar com o apoio de outras profissionais que atuavam na escola - professoras e coordenadora - foi importante para o enfrentamento das dificuldades relacionadas ao trabalho pedagógico na creche. Renata ainda relata que consultou livros sobre o assunto, já Graziela indica que a construção de experiência prática também foi um fator importante que Ihe auxiliou. Neste sentido, Oliveira (2018, p. 262) conclui que as professora iniciantes participantes "[...] recorreram aos conhecimentos provenientes de seus processos de socialização [...], da aprendizagem com os pares [...] para aspectos mais básicos e rotineiros [...] e da formação inicial que, mesmo com fragilidades, possibilitou $\mathrm{o}$ aprendizado de conhecimentos" relativos ao trabalho pedagógico.

\section{"APRENDIZAGEM DA DOCÊNCIA: O QUE REVELAM AS TRAJETÓRIAS DAS PROFESSORAS DE EDUCAÇÃO INFANTIL DA REDE MUNICIPAL DE RIBEIRÃO PRETO" (TOSTA, 2019)}

A dissertação de mestrado de Tosta (2019, p. 21) teve como objetivo geral "[...] investigar como ocorre a aprendizagem da docência de professoras que atuam na Educação Infantil na rede municipal de Ribeirão Preto (SP)". Como objetivos específicos, a dissertação buscou conhecer e analisar a trajetória de vida e de formação e profissional das professoras que atuam na Educação Infantil de Ribeirão Preto; identificar e analisar quais as concepções de formação continuada que essas professoras possuem; investigar as necessidades formativas das professoras (TOSTA, 2019).

Para abordar a aprendizagem da docência na Educação Infantil na parte de fundamentação teórica, primeiramente a pesquisadora discorre brevemente sobre os percursos históricos da formação de professores no Brasil, contextualizando historicamente a Educação Infantil (posteriormente, na parte metodológica, discorreu-se sobre os percursos históricos da Educação Infantil especificamente em Ribeirão Preto). Por fim, a pesquisadora apresenta os conceitos que embasam teoricamente a pesquisa: "[...] aprendizagem da docência; desenvolvimento profissional docente; fases, ciclos ou etapas da carreira docente e suas características" (TOSTA, 2019, p. 23).

Trata-se de uma pesquisa de abordagem qualitativa: foram aplicados questionários e realizadas entrevistas semiestruturadas. Primeiramente, foram enviados 30 questionários iniciais para as professores de uma unidade escolar de Ribeirão Preto. Dos 30 questionários, houve 26 devolutivas. Os questionários continham perguntas sobre: idade, gênero, etnia (cor/raça) e tempo de atuação como docente; perguntas abertas sobre trajetória profissional; perguntas abertas sobre formação inicial e continuada. Todas as 26 professoras que responderam o questionário foram convidadas para participar da entrevista semiestruturada, mas apenas seis delas aceitaram o convite. Das seis entrevistas, foram selecionadas apenas três para análise, por serem as entrevistas cujos dados obtidos ajudariam a compreender o problema de pesquisa. 
Para a análise dos dados, a pesquisadora construiu os seguintes eixos de análise: experiências como aluna e escolha da profissão; formação inicial, aprendizagem e início da docência; concepções de formação continuada; demandas formativas manifestas (TOSTA, 2019). Os resultados da dissertação apontam que: a qualidade do atendimento às crianças da Educação Infantil passa pela formação dos professores que nela atuam (mas não é a única/exclusiva condição para que essa qualidade seja alcançada); "[...] os professores aprendem a ser professores durante sua vida e por isso todas as etapas precisam ser cuidadosamente pensadas, especialmente os anos iniciais da carreira" (TOSTA, 2019, p. 99); a Educação Infantil possui especificidades que precisam ser levadas em consideração na hora de formular propostas de formação, em especial a formação continuada de professoras dessa etapa; os professores da Educação Infantil precisam ser ouvidos sobre o que desejam e esperam da própria formação que recebem (e, mais do que isso, deveriam estar inseridos na construção dessas propostas formativas).

A pesquisa também pôde identificar algumas necessidades formativas, manifestadas pelas professoras: parcerias com outros profissionais; trocas de experiência entre pares; discussão das dificuldades em grupos; divulgação de práticas educativas bem sucedidas (práticas exitosas); temas específicos da Educação Infantil (como, por exemplo, cuidar e brincar); cursos que articulem teoria e prática; congressos e feiras pedagógicas; autonomia para escolher o que irá estudar (e que cursos de formação continuada fazer); formação voltada para a necessidade de cada escola; formação pedagógica de outros profissionais que trabalham na escola; "respiros" (pausas) pedagógicos.

Com relação à resposta para a pergunta de pesquisa (como ocorre a aprendizagem da docência das professoras que atuam na Educação Infantil na rede municipal de ensino de Ribeirão Preto?), foi possível concluir que: "[...] não há um modo único, uma vez que a aprendizagem de ser professor se dá ao longo da vida e que cada sujeito tem experiências próprias, as quais atribuem diferentes sentidos" (TOSTA, 2019, p. 99).

\section{PARA ONDE OS ESTUDOS NOS ORIENTAM?}

Considera-se aqui que a formação profissional docente é um processo contínuo e que as experiências vivenciadas dentro e fora do contexto escolar influenciarão a compreensão do professor sobre a docência, sobre a prática pedagógica, sobre a construção da identidade profissional (MARCELO GARCIA, 2010). Neste sentido, as especificidades de cada contexto, sujeitos, metodologia do estudo, bem como dos instrumentos para produção de dados, sinalizam que o caminho formativo das professoras da Educação Infantil participantes das pesquisas analisadas - dada a trajetória de vida - caminham ora de forma mais intensa, ora mais amena.

Referente a isso, a experiência de aproximação com a tese e as dissertações permitiu identificar algumas questões que merecem destaque:

Sobre a "formação inicial", podemos inferir que esta precisa ser pensada e situada em bases que possibilitem elementos constitutivos acerca da especificidade do trabalho e da rotina da Educação Infantil. Ser professora de bebês e crianças de até 5 anos e 11 meses exige habilidades profissionais que diferem-se das professoras que atuam em outras etapas de ensino (BRASIL, 2010). Neste sentido, os processos de "cuidar e educar" na primeira infância acontecem de modo articulado com vivências de mundo nas múltiplas linguagens presentes no espaço-tempo do ser criança na contemporaneidade. As professoras entrevistadas na pesquisa de Barros (2015) salientaram essa especificidade da docência na Educação Infantil ao demonstrarem preocupação no desenvolvimento de uma prática pedagógica que respeite bebês e crianças em suas singularidades e necessidades. A concepção semelhante das participantes sobre o fazer docente nesta etapa educacional pode estar relacionada à formação inicial recebida.

A experiência de leitura e apreciação das pesquisas apresentadas neste artigo também nos dá condições para afirmar que, dados resultados das investigações, os cursos de Pedagogia dos contextos analisados possibilitaram mecanismos de resistências por parte de algumas professoras iniciantes. Foi, assim, possível identificar que elas sabem o que fazer, muito embora não reconheçam de onde tais habilidades são oriundas, como no caso da pesquisa de Voltarelli (2013). Apesar disso, também é evidente que muitas das dificuldades enfrentadas pelas iniciantes assim como a condução de algumas práticas pedagógicas - como explicitado na tese de Oliveira (2018) - são oriundas da fragilidade 
dos programas formativos em relação à estrutura e organicidade do currículo da licenciatura.

Frente aos estudos (VOLTARELLI, 2013; BARROS, 2015; OLIVEIRA, 2018; TOSTA, 2019), podemos inferir ainda que programas de indução à docência, como o PIBID e o Residência Pedagógica, podem, no tempo presente, auxiliar professoras em formação em sua inserção na cultura da instituição de Educação Infantil. Tal fato contribuirá, sem dúvida, para aproximar a futura professora ao contexto real da docência e, com isso, superar algumas dificuldades acerca da constituição de uma profissionalidade e identidade da professora de crianças pequenas.

Em relação ao "início da carreira", de modo comum, todos os trabalhos localizados no período de busca apresentam semelhanças nos resultados em relação às dificuldades das professoras iniciantes, corroborando dados da literatura especializada na temática. Exprimem aspectos da inserção das professoras em distintas regiões do Estado de São Paulo, identificam características do habitus professoral das redes e secretarias em que as docentes ingressaram na carreira e, em alguns casos, denunciam relações de poder postas na hierarquização entre professoras experientes e iniciantes. As bases teóricas e metodológicas dos estudos aqui referenciados permitem-nos afirmar que existe uma correlação entre autores para o tratamento das questões inerentes aos ritos de iniciação e ainda que a forma como a professora da Educação Infantil é vista e suas ações são concebidas precisam, urgentemente, serem repensadas.

No que respeita a "formação continuada", os trabalhos indicam que há a necessidade de se criar espaços e situações em que ocorra a troca entre pares, em especial com docentes mais experientes (troca de saberes, de experiências, de conteúdos etc.). Os resultados dos estudos revelam que a implementação de um trabalho de natureza colaborativa poderia ser a base para minimizar muitas das demandas e necessidades formativas manifestadas. Além da troca entre pares, os trabalhos também indicam que as iniciativas de formação continuada devem ser pensadas especificamente para a Educação Infantil, visando promover processos de reconstrução de saberes e práticas que são próprias dessa etapa para aprimoramento do fazer docente.

Diante do exposto, ao refletirmos "para onde os estudos nos orientam", entendemos que existe uma tríade fundamental ao processo de constituir-se professora da Educação Infantil, a saber: formação inicial-inserção profissionalformação continuada. Tal como a indissociabilidade do termo "cuidar e educar", defendemos o posicionamento de que para o professor iniciante precisamos pensar em um terceiro espaço formativo, de acordo os pressupostos de Nóvoa (2017). Para nós, o terceiro espaço de formação de professores é a articulação indissociável da tríade exposta, constituindo-se num "trinômio" (formação inicialinserção profissional-formação continuada). Analogicamente ao trinômio matemático, que é uma expressão algébrica de três termos, em que "a" e "b" são quantidades conhecidas (formação inicial e continuada), "c" (inserção profissional) é um elemento variável. Dadas as especificidades da atuação em cada espaço de início da docência, este elemento/variável tem influência do contexto e das pessoas, por isso, é preciso encarar tal fase da vida docente como projeto coletivo para que possamos solucionar o problema e atender as necessidades formativas.

\section{CONSIDERAÇÕES FINAIS}

Ao longo do artigo procuramos responder o seguinte questionamento: Quais necessidades formativas são apontadas em teses e dissertações do Estado de São Paulo em relação ao início da carreira docente na Educação Infantil?

Na busca por respostas, empreendemos esforços em um trabalho de pesquisa, do tipo "Estado da Arte", junto aos repositórios institucionais de Universidades paulistas com cursos de mestrado e doutorado vigentes. Diante do mapeamento, foi possível verificar a escassez, entre 2009 e 2019, de investigações que se preocuparam com a formação, inserção, atuação e prática das professoras iniciantes na creche e na pré-escola. Ilustra essa assertiva o fato de que, dentre 52 trabalhos, apenas quatro dizem respeito ao tema abordado por nós: uma tese de doutorado defendida na PUC (OLIVEIRA; 2018) e três dissertações de mestrado, destas duas da UFSCar (VOLTARELLI, 2013; TOSTA, 2009) e uma da UNESP de Araraquara (BARROS, 2015).

A aproximação com os dizeres das pesquisas em xeque trouxe o entendimento de que as necessidades formativas das professoras iniciantes na Educação Infantil se relacionam à: i) concepções pedagógicas na perspectiva da profissionalização docente; ii) competências para 
o planejamento de uma prática docente coerente às especificidades da Educação Infantil; iii) dimensão teórica articulada à prática pedagógica e aos diferentes contextos institucionais.

Com base nas necessidades formativas dos contextos investigativos apresentados ao longo deste texto, salientamos, em decorrência do que os dados anunciaram, ser preciso práticas interventivas com a professora. Isto é, são necessárias pesquisas que avaliem proposições de auxílio ao docente em início de carreira. O conhecimento das dificuldades oriundas do processo de inserção na docência já é bem explorado por diferentes trabalhos que se dedicam a pensar/discutir o assunto. Neste sentido, conhecemos muito sobre a formação, inserção e o que sentem os professores sobre o começo do caminho da docência, precisamos agora pensar e construir, coletivamente, processos de apoio à indução profissional, buscando alternativas propositivas de sanar dificuldades e contribuir com o desenvolvimento profissional, especificamente da professora de Educação Infantil.

Caminhamos para conclusão lembrando que também fora propósito e destaque do presente trabalho apontar caminhos e/ou alternativas para sanar os problemas decorrentes da iniciação à docência. Dado contexto e resultados dos trabalhos analisados, entendemos que as alternativas são: o trabalho colaborativo, programas de apoio, inserção e permanência, políticas de acompanhamento docente, instituir e reconhecer o papel da instituição na aprendizagem e formação docente. Especificamente na formação inicial entendemos ser relevante fortalecer a identidade da futura professora de Educação Infantil, o que pode se materializar por meio de projetos de ensino/pesquisa/extensão que permitam experienciar, mesmo que minimamente, a cultura do trabalho docente e a cultura organizacional do cotidiano das instituições de atendimento à infância, o que pode vir a contribuir para o fortalecimento dos processos de profissionalização docente e ainda para romper com a visão histórica do caráter assistencialista da Educação Infantil, o qual ainda hoje insiste em ser elemento dificultador à ampliação de repertórios de atuação com as crianças de modo a fortalecer práticas de cuidado e educação.
BARROS, B. C. de. Ser professora iniciante na Educação Infantil: aprendizagens e desenvolvimento profissional em contexto de enfrentamentos e superações de dilemas. 2015. 159f. Dissertação (Mestrado em Educação) Faculdade de Ciências e Letras de Araraquara da Universidade Estadual Paulista "Júlio de Mesquita Filho" - FACLAR/UNESP, Araraquara, 2015. Disponível

em:

https://repositorio.unesp.br/bitstream/handle/1 1449/126379/000840607.pdf?sequence=1\&isAllo wed=y. Acesso em: 12 jul. 2020.

BRASIL. Ministério da Educação. Conselho Nacional de Educação Conselho Pleno. Resolução CNE/CP № 1, DE 15 de maio de 2006. Institui Diretrizes Curriculares Nacionais para o Curso de Graduação em Pedagogia, licenciatura. Brasília, 2006. Disponível em: http://portal.mec.gov.br/cne/arquivos/pdf/rcp01 06.pdf. Acesso em: 2 abr. 2019.

BRASIL, Ministério da Educação. Secretaria de Educação Básica. Diretrizes Curriculares Nacionais para a Educação Infantil. Brasília: MEC, SEB. 2010. Disponível em: http://portal.mec.gov.br/index.php?option=com docman\&view=download\&alias=9769-

diretrizescurriculares-

2012\&category slug=janeiro-2012pdf\&Itemid=30192. Acesso em: 13 jun. 2020.

BRASIL. Presidência da República (Casa Civil). Subchefia para Assuntos Jurídicos. Governo Federal. Lei de Diretrizes e Bases da Educação Nacional: Lei n. 9.394, de 20 de Dezembro de 1996. Brasília, 1996. Disponível em: http://www.planalto.gov.br/ccivil 03/leis/19394. html. Acesso em: 15 jul. 2020.

BROSTOLIN, M. R.; OlIVEIRA, E. A. C. de. Educação Infantil: dificuldades e desafios do professor iniciante. Interfaces da Educação, Paranaíba, v.4, n.11, p.41-56, 2013. Disponível em:

https://periodicosonline.uems.br/index.php/inter faces/article/view/520/486. Acesso em: 23 maio 2020.

CAMPOS, M. M.. et al. Profissionais de creche Educação pré-escolar: desafios e alternativas, Cadernos CEDES, Campinas, v. 9, p. 39-66, 1999.

\section{REFERÊNCIAS}


CARVALHO, R. P. A literatura infantil e a Matemática: um estudo com crianças de 5 e 6 anos de idade da Educação Infantil. 2010. 117f. Dissertação (Mestrado em Educação) - Pontifícia Universidade Católica, PUC/SP. São Paulo. 2010. Disponível em: https://tede2.pucsp.br/bitstream/handle/10832/ 1/Regiane\%20Perea\%20Carvalho.pdf. Acesso em: 23 maio 2020.

CERISARA, A. B. O Referencial Curricular Nacional para a Educação Infantil no contexto das reformas. Educ. Soc., Campinas, v. 23, n. 80, p. 326-345, set. 2002 . Disponível em: https://www.scielo.br/pdf/es/v23n80/12935.

Acesso em: 13 jan. 2020.

DOI: $10.1590 /$ S0101-73302002008000016

CIRÍACO, K. T. Professoras iniciantes e o aprender a ensinar Matemática em um grupo colaborativo. 2016. 334f. Tese (Doutorado em Educação) - Faculdade de Ciências e Tecnologia da Universidade Estadual Paulista "Júlio de Mesquita Filho" - FCT/UNESP, Presidente Prudente-SP, 2016. Disponível em: https://repositorio.unesp.br/bitstream/handle/1 1449/139512/ciriaco kt dr prud.pdf?sequence= 3\&isAllowed=y. Acesso em: 20 abr. 2020.

CIRÍACO, K. T.; SILVA, L. M. da. Mapeamento da produção científica brasileira sobre professores iniciantes (2006-2016) - Do "Choque com o real" à "Descoberta". Teoria e Prática da Educação, Maringá, v. 23, n. 1, p. 167-197, Jan./Abr. 2020. Disponível

em:

http://periodicos.uem.br/ojs/index.php/TeorPrat Educ/article/view/51861/751375150494. Acesso em: 15 ago. 2020.

DOI: $10.4025 /$ tpe.v23i1.51861

CRUZ, S. P. S.; BATISTA NETO, J. A polivalência no contexto da docência nos anos iniciais da escolarização básica: refletindo sobre experiências de pesquisas. Rev. Bras. Educ. [online], Rio de Janeiro, v. 17, n. 50, p. 385-398, 2012. Disponível em: http://www.scielo.br/pdf/rbedu/v17n50/v17n50 a08.pdf. Acesso em: 28 abr. 2019 DOI: $10.1590 /$ S1413-24782012000200008

DENZIN, N. K.; LINCOLN, Y. S. Handbook of qualitative research. London: Sage Publication: 1994.
FERREIRA, N. S. A. As pesquisas denominadas "estado da arte". Educação \& Sociedade, Campinas, v. 23, n. 79, p. 257-272, ago. 2002. Disponível em: https://www.scielo.br/pdf/es/v23n79/10857.pdf. Acesso em: 25, jun. 2020. DOI:10.1590/S0101-73302002000300013

FONTANA, R. C. Trabalho e subjetividade. Nos rituais da iniciação, a constituição do ser professora. Cad. CEDES [online], Campinas, v. 20, n. 50, p. 103-119, 2000. Disponível em: http://www.scielo.br/pdf/ccedes/v20n50/a08v20 50.pdf. Acesso em: 12 mar. 2019. DOI: S0101-32622000000100008

FREITAS, M. N. C. Organização escolar e socialização profissional de professores iniciantes. Cadernos de Pesquisa, São Paulo, n. 155, p. 155-172, mar. 2002. Disponível: http://www.scielo.br/pdf/cp/n115/a06n115.pdf. Acesso: 2 fev. 2019.

DOI: $10.1590 /$ S0100-15742002000100006

HUBERMAN, M. O ciclo de vida profissional dos professores. In: NÓVOA, A. (Org.). Vidas de professores. 2. ed. Porto: Porto, 2000. p. 31-61.

KUHLMANN JR., M. Histórias da educação infantil brasileira. Revista Brasileira de Educação, Rio de Janeiro, n. 14, p. 5-19, Mai-Ago. 2000. Disponível em:

https://www.scielo.br/pdf/rbedu/n14/n14a02.pd f. Acesso em: 20 abr. 2020. DOI: $10.1590 /$ S1413-24782000000100002

LIMA, E. F. Começando a ensinar: começando a aprender? 1996. 136f. Tese (Doutorado em Educação) - Centro de Educação e Ciências Humanas da Universidade Federal de São Carlos, CECH/UFSCar, São Carlos, 1996.

LORENZATO, S. Educação Infantil e percepção matemática. Campinas: Autores Associados. 2008.

MARCELO GARCÍA, C. O professor iniciante, a prática pedagógica e o sentido da experiência. Revista Brasileira sobre Formação Docente, Belo Horizonte, v. 02, n. 03, p. 11-49, ago./dez. 2010. Disponível em: http://formacaodocente.autenticaeditora.com.br Lartigo/exibir/8/18/1. Acesso em: 25 fev. 2019. 
MARIANO, A. L. S. A construção do início da docência: um olhar a partir das produções da ANPEd e do ENDIPE. 2006. 156f. Dissertação (Mestrado em Educação) - Centro de Educação e Ciências Humanas da Universidade Federal de São Carlos - CECH/UFSCar. São Carlos, 2006. Disponível em: https://repositorio.ufscar.br/bitstream/handle/uf scar/2796/DissALSM. pdf?sequence=1. Acesso em: 25 maio 2020.

NÓVOA, A. Firmar a posição como professor, afirmar a profissão docente. Cad. Pesqui., São Paulo, v. 47, n. 166, p. 1106-1133, 2017. Disponível em:

https://www.scielo.br/pdf/cp/v47n166/19805314-cp-47-166-1106.pdf. Acesso em: 15 abr. 2020.DOI: 10.1590/198053144843

NÚÑEZ, I. B. Estudo das necessidades formativas de professores(as) do Ensino Médio no contexto das reformas curriculares. In: REUNIÃO ANUAL DA ANPED, 27., 2004. Caxambu-MG. Anais... Caxambu: ANPED, 2004. Disponível em: http://27reuniao.anped.org.br/gt08/t089.pdf.

Acesso em: 4 mar. 2019.

OLIVEIRA, M. O. de. A inserção profissional e a atuação docente na Educação Infantil. 2018. 300f. Tese (Doutorado em Educação) - Pontifícia Universidade Católica de São Paulo - PUC/SP. $2018 . \quad$ Disponível em: https://sapientia.pucsp.br/bitstream/handle/209 27/2/Midi\%c3\%a3\%200linto\%20de\%200liveira.p df. Acesso em: 15 jul. 2020.

ROCHA, E. A. C. A pesquisa em educação infantil no Brasil: trajetória recente e perspectiva de consolidação de uma pedagogia. Florianópolis: UFSC: Centro de Ciências da Educação: Núcleo de Publicações -NUP, 1999.

RODRIGUES, A.; ESTEVES, M. A análise de necessidade na formação de professores. Porto: Porto Editora, 1993.
TARDIF, M. Saberes docentes e formação profissional. 8. ed. Petrópolis, RJ: Vozes, 2007.

TOSTA, T. D. O. Aprendizagem da docência: o que revelam as trajetórias das professoras de Educação Infantil da rede municipal de Ribeirão Preto. 2019. 115f. Dissertação (Mestrado em Educação) - Centro de Educação e Ciências Humanas da Universidade Federal de São Carlos - CECH/UFSCar. São Carlos, 2019. Disponível em: https://repositorio.ufscar.br/bitstream/handle/uf scar/11181/Disserta\%c3\%a7\%c3\%a30\%20Tawan a\%20Tosta\%20.pdf?sequence=6\&isAllowed =y.

Acesso em: 16 jun. 2020.

VEENMAN, S. Problemas percebidos de professores iniciantes. Review of Educational Research, v. 54, n. 2. 1984. Disponível em: https://journals.sagepub.com/doi/10.3102/0034 6543054002143. Acesso em: 15 jul. 2020. DOI:10.3102/00346543054002143

VOLTARELLI, M. A. Aprendizagem profissional da docência: que saberes o(a) professor(a) tem para atuar em creche? 2013. 247f. Dissertação (Mestrado em Educação) - Centro de Educação e Ciências Humanas da Universidade Federal de São Carlos - CECH/UFSCar. São Carlos, 2013. Disponível em: https://repositorio.ufscar.br/bitstream/handle/uf scar/2643/4896. pdf? sequence=1\&isAllowed =y.

Acesso em: 15 jul. 2020.

YAMASHIRO, C. R. C.; LEITE, Y. U. F. A emergência da análise de necessidades de formação de professores: pesquisas afins. In: SEMINÁRIO DE PESQUISA EM EDUCAÇÃO DA REGIÃO SUL, 9., 2012, Caxias do Sul. Anais... Caxias do Sul: Universidade de Caxias do Sul, 2012. p.1-15. Disponível em: http://www.ucs.br/etc/conferencias/index.php/a npedsul/9anpedsul/paper/viewFile/787/558.Aces so: 12 fev. 2019. 